\title{
Thiazole Functionalized Terpolymer Donors Obtained via Random Ternary Copolymerization for High-Performance Polymer Solar Cells
}

Zhihui Liao, ${ }^{1,2}$ Ke Yang, ${ }^{3}$ Licheng Hou, ${ }^{1,2}$ Jun Li, ${ }^{4}$ Jie Lv, ${ }^{1,2}$ Ranbir Singh, ${ }^{5}$ Manish Kumar, ${ }^{5}$ Qianqian Chen, ${ }^{1}$ Xiyue Dong, ${ }^{1,2}$ Tongle $\mathrm{Xu},{ }^{1,2}$ Chao Hu, ${ }^{1}$ Tainan Duan, ${ }^{1}$ Zhipeng Kan, ${ }^{1}$ Shirong Lu, ${ }^{1, *}$ and Zeyun $\mathrm{Xiao}^{1, *}$

${ }^{1}$ Chongqing Institute of Green and Intelligent Technology, Chongqing School, University of Chinese Academy of Sciences (UCAS Chongqing), Chinese Academy of Sciences, Chongqing 400714, P. R. China

${ }^{2}$ University of Chinese Academy of Sciences, Beijing 100049, P. R. China

3 Key Laboratory of Low-Grade Energy Utilization Technologies and Systems (Ministry of Education), School of Power Engineering, Chongqing University, Chongqing 400044, P.R. China

${ }^{4}$ Library \& Information Center, Anhui University of Finance and Economics, Bengbu 233030, P. R. China

${ }^{5}$ Department of Energy \& Materials Engineering, Dongguk University, Seoul 04620, South Korea

Pohang Accelerator Laboratory, Pohang University of Science and Technology, Pohang 37673, South Korea.

*E-mail: lushirong@cigit.ac.cn; xiao.z@cigit.ac.cn 


\section{EXPERIMENTAL SECTION}

\section{Materials and Instruments}

All reagents and chemicals were commercially available. Monomer of BDT-2F and materials PM6 and Y6 were purchased from Solarmer Co., Ltd. (Beijing, China). Monomer of BDD was purchased from Derthon Co., Ltd. Monomer of E-Tz was purchased from Energy Chemical., Ltd. 1,8-diiodooctane (DIO) and chloronaphthalene $(\mathrm{CN})$ additive were supplied by Sigma Aldrich. The Phen-NaDPO was purchased from Bellingway Technology Co., Ltd. ${ }^{1} \mathrm{NMR}$ spectra were recorded on a Bruker Ascend $400 \mathrm{MHz}$ spectrometer using $\mathrm{CDCl}_{3}$ and $\mathrm{CD}_{2} \mathrm{Cl}_{2}$ as the solvent. Molecular weight and polydispersity index of the polymer were determined by gel permeation chromatography (GPC) analysis with polystyrene as standard (PL-GPC220, using trichlorobenzene (TCB) as eluent at a flow rate of $1.0 \mathrm{~mL} / \mathrm{min}$ at $150{ }^{\circ} \mathrm{C}$. Thermogravimetric analysis (TGA) was conducted on a Perkin-Elmer TGA-7 with a heating rate of $20 \mathrm{~K} / \mathrm{min}$ under nitrogen. The cyclic voltammetry was recorded with a computer controlled PP211 electrochemical workstation using polymer films on platinum electrode $\left(1.0 \mathrm{~cm}^{2}\right)$ as the working electrode, a platinum wire as the counter electrode and $\mathrm{Ag} / \mathrm{AgCl}(0.1 \mathrm{M})$ as the reference electrode in an anhydrous and argon-saturated solution of $0.1 \mathrm{M}$ of tetrabutylammonium hexafluorophosphate $\left(\mathrm{Bu}_{4} \mathrm{NPF}_{6}\right)$ in acetonitrile at a scanning rate of $20 \mathrm{mV} \cdot \mathrm{s}^{-1}$. The $\mathrm{CV}$ curves were recorded versus the potential of SCE, which was calibrated by the ferrocene-ferrocenium $\left(\mathrm{Fc} / \mathrm{Fc}^{+}\right)$redox couple $(4.8 \mathrm{eV}$ below the vacuum level). The HOMO and LUMO levels were calculated using the equations: $E_{\mathrm{HOMO}}=-\mathrm{e}\left(E_{\mathrm{ox}}+4.8\right.$ 
$\left.-E_{\mathrm{Fc} / \mathrm{Fc}^{+}}\right) \mathrm{V}, E_{\mathrm{LUMO}}=-\mathrm{e}\left(E_{\mathrm{red}}+4.8-E_{\mathrm{Fc} / \mathrm{Fc}^{+}}\right) \cdot{ }^{1-3}$ AFM using a Digtial Instrumental Nanoscope 31 operated in the tapping mode, the film was prepared as the same as device fabrication to ensure the reliability and authenticity. AFM sample preparation: The ITO glass substrates were cleaned followed by ultrasonic treatment in detergent deionized water, acetone, and isopropyl alcohol for $30 \mathrm{~min}$. each. After treating with plasma for $3 \mathrm{~min}$. PEDOT:PSS layer spin-cast on top of the ITO substrates at 4000 $\mathrm{rpm}$ for $20 \mathrm{~s}$ and heated at $160{ }^{\circ} \mathrm{C}$ in ambient atmosphere for $30 \mathrm{~min}$. Active layer was spun at $2800 \mathrm{rpm}$ for $30 \mathrm{~s}$ from the solution of polymers:Y6 at weight ratio of 1:1.3 with a total concentration of $17 \mathrm{mg} \mathrm{ml}^{-1}$ in chloroform, and then thermal annealed at $100{ }^{\circ} \mathrm{C}$ for $10 \mathrm{~min}$. TEM sample preparation: The ITO glass substrates were cleaned followed by ultrasonic treatment in detergent deionized water, acetone, and isopropyl alcohol for $30 \mathrm{~min}$. each. After treating with plasma for 3 min. PEDOT:PSS layer spin-cast on top of the ITO substrates at $4000 \mathrm{rpm}$ for $20 \mathrm{~s}$ and generated at $160{ }^{\circ} \mathrm{C}$ in ambient atmosphere for $30 \mathrm{~min}$. Active layer were spun at $2800 \mathrm{rpm}$ for $30 \mathrm{~s}$ from the solution of polymers:Y6 at weight ratio of 1:1.3 with a total concentration of $17 \mathrm{mg}$ $\mathrm{ml}^{-1}$ in chloroform, and then thermal annealed at $100{ }^{\circ} \mathrm{C}$ for $10 \mathrm{~min}$. And then the film was extracted in water and put on the copper grid. The current-voltage $\left(J^{1 / 2}-V\right)$ curves evaluated by SCLC method was fitted by $\mathrm{J}=9 \varepsilon_{0} \varepsilon r \mu \mathrm{V}^{2} / 8 \mathrm{~L}^{3}$, where $\varepsilon_{0}$ is the permittivity of free space and constant at $8.85 \times 10^{-12} \mathrm{~F} / \mathrm{m}, \varepsilon \mathrm{r}$ is the dielectric constant of the polymer and it is assumed to be $2, \mu$ is the charge mobility, $\mathrm{V}$ is the applied voltage across the device, and $\mathrm{L}$ is the thickness of the active layer.

\section{Synthesis of polymers}


Four polymers were synthesized using a palladium-catalyzed Stille coupling reaction. OPz1: $0.1 \mathrm{mmol}(940.5 \mathrm{mg})$ monomer of BDT-2F and $0.095 \mathrm{mmol}(72.8 \mathrm{mg})$ bromide monomer of BDD and $0.005 \mathrm{mmol}(1.58 \mathrm{mg}) \mathrm{E}-\mathrm{Tz}$; OPz2: $0.1 \mathrm{mmol}(940.5 \mathrm{mg})$ monomer of BDT-2F and $0.09 \mathrm{mmol}(69 \mathrm{mg})$ bromide monomer of $\mathrm{BDD}$ and 0.01 mmol (3.15mg) E-Tz; OPz3: $0.1 \mathrm{mmol}(940.5 \mathrm{mg})$ monomer of BDT-2F and 0.08 mmol (61.3mg) bromide monomer of BDD and $0.02 \mathrm{mmol}(6.3 \mathrm{mg}) \mathrm{E}-\mathrm{Tz}$; OPz4: 0.1 mmol (940.5mg) monomer of BDT-2F and $0.1 \mathrm{mmol}(31.5 \mathrm{mg}) \mathrm{E}-\mathrm{Tz}$, were dissolve in dry toluene $(10 \mathrm{~mL}) . \mathrm{Pd}\left(\mathrm{PPh}_{3}\right)_{4}(8 \% \mathrm{mmol} 9.2 \mathrm{mg})$ was added into the mixtures after being flushed with argon for five minutes. Then, the reaction mixtures were purged with argon for another $10 \mathrm{~min}$. The reactions were stirred at $110^{\circ} \mathrm{C}$ (preheat) for $4 \mathrm{~h}$. The obtained copolymers were purified by Soxhlet extraction (the solvent using methanol, acetone and n-hexane and chloroform, respective), and the primary polymers followed by a fast silica gel column chromatography with chloroform as solvent to remove the oligomers and other impurities. The polymer was then precipitated in methanol $(60 \mathrm{~mL})$ and dried under vacuum for $12 \mathrm{~h}$ before use. The yields are around $60 \%$.

BDD: ${ }^{1} \mathrm{H}$ NMR (400 MHz, $\left.\mathrm{CDCl}_{3}\right) \delta(\mathrm{ppm}): 7.37(\mathrm{~d}, 1 \mathrm{H}), 6.99(\mathrm{~d}, 1 \mathrm{H}), 3.31(\mathrm{~m}, 2 \mathrm{H})$, $1.68(\mathrm{~m}, 1 \mathrm{H}), 1.22-1.41(\mathrm{~m}, 9 \mathrm{H}), 0.9(\mathrm{~m}, 6 \mathrm{H})$.

BDT-2F: ${ }^{1} \mathrm{H}$ NMR (400 MHz, $\left.\mathrm{CDCl}_{3}\right) \delta(\mathrm{ppm}): 7.67(\mathrm{~s}, 1 \mathrm{H}), 6.99(\mathrm{~s}, 1 \mathrm{H}), 3.25(\mathrm{~d}, 2 \mathrm{H})$, $1.45(\mathrm{~m}, 1 \mathrm{H}), 1.25-1.36(\mathrm{~m}, 9 \mathrm{H}),, 0.9-0.98(\mathrm{~m}, 6 \mathrm{H}), 0.42(\mathrm{t}, 9 \mathrm{H})$ E-Tz: ${ }^{1} \mathrm{H}$ NMR (400 MHz, $\left.\mathrm{CDCl}_{3}\right) \delta(\mathrm{ppm}): 4.45(\mathrm{t}, 2 \mathrm{H}), 1.41-1.6(\mathrm{~m}, 3 \mathrm{H})$. 
PM6: ${ }^{1} \mathrm{H}$ NMR (400 MHz, $\left.\mathrm{CDCl}_{3}\right) \delta(\mathrm{ppm}): 7.52(1 \mathrm{H}), 7.0(1 \mathrm{H}), 3.51$ (m, $\left.7.7 \mathrm{H}\right), 2.82$ (m, 16.26 H), 0.88-1.56 (m, 264.4H).

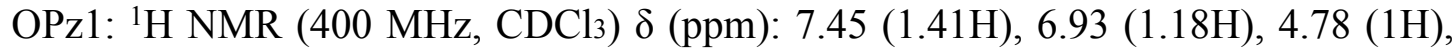
$2.75(39.29 \mathrm{H}), 0.8-1.5(3627.54 \mathrm{H})$

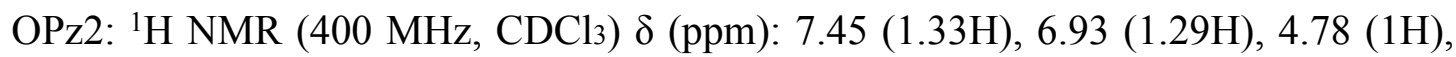
$2.75(\mathrm{~m}, 40.04 \mathrm{H}), 0.8-1.5(\mathrm{~m}, 421 \mathrm{H})$.

OPz3: ${ }^{1} \mathrm{H}$ NMR $\left(400 \mathrm{MHz}, \mathrm{CDCl}_{3}\right) \delta(\mathrm{ppm}): 7.45(0.41 \mathrm{H}), 6.93(0.41 \mathrm{H}), 4.36(1 \mathrm{H})$, $3.22(\mathrm{~m}, 5.32 \mathrm{H}), 2.75(\mathrm{~m}, 7.5 \mathrm{H}), 0.8-1.5(\mathrm{~m}, 135.4 \mathrm{H})$.

OPz4: ${ }^{1} \mathrm{H}$ NMR (400 MHz, $\left.\mathrm{CDCl}_{3}\right) \delta(\mathrm{ppm}): 4.44(1 \mathrm{H}), 2.82(\mathrm{~m}, 2.54 \mathrm{H}), 0.8-1.5(\mathrm{~m}$, $37.79 \mathrm{H})$.

Elemental analysis calcd (\%) for OPz1: $\mathrm{C}=66.84 \%, \mathrm{H}=6.31 \%, \mathrm{~S}=20.96 \%, \mathrm{~N} \%$ $0.06 \%$. Found: $\mathrm{C}=66.52 \%, \mathrm{H}=6.26 \%, \mathrm{~S}=20.96 \%, \mathrm{~N} \%=0.07 \%$.

Elemental analysis calcd (\%) for OPz2: $\mathrm{C}=66.69 \%, \mathrm{H}=6.29 \%, \mathrm{~S}=20.96 \%, \mathrm{~N} \%$ $0.12 \%$. Found: $\mathrm{C}=67.36 \%, \mathrm{H}=6.8 \%, \mathrm{~S}=20.83 \%, \mathrm{~N} \%=0.12 \%$.

Elemental analysis calcd (\%) for OPz3: $\mathrm{C}=66.24 \%, \mathrm{H}=6.18 \%, \mathrm{~S}=21.23 \%, \mathrm{~N} \%$ $0.24 \%$. Found: $\mathrm{C}=64.84 \%, \mathrm{H}=7.21 \%, \mathrm{~S}=20.85 \%, \mathrm{~N} \%=0.28 \%$.

Elemental analysis calcd (\%) for OPz4: $\mathrm{C}=62.80 \%, \mathrm{H}=6.04 \%, \mathrm{~S}=20.44 \%, \mathrm{~N} \%$ $1.79 \%$. Found: $\mathrm{C}=62.40 \%, \mathrm{H}=5.86 \%, \mathrm{~S}=20.30 \%, \mathrm{~N} \%=1.82 \%$. 
(a)

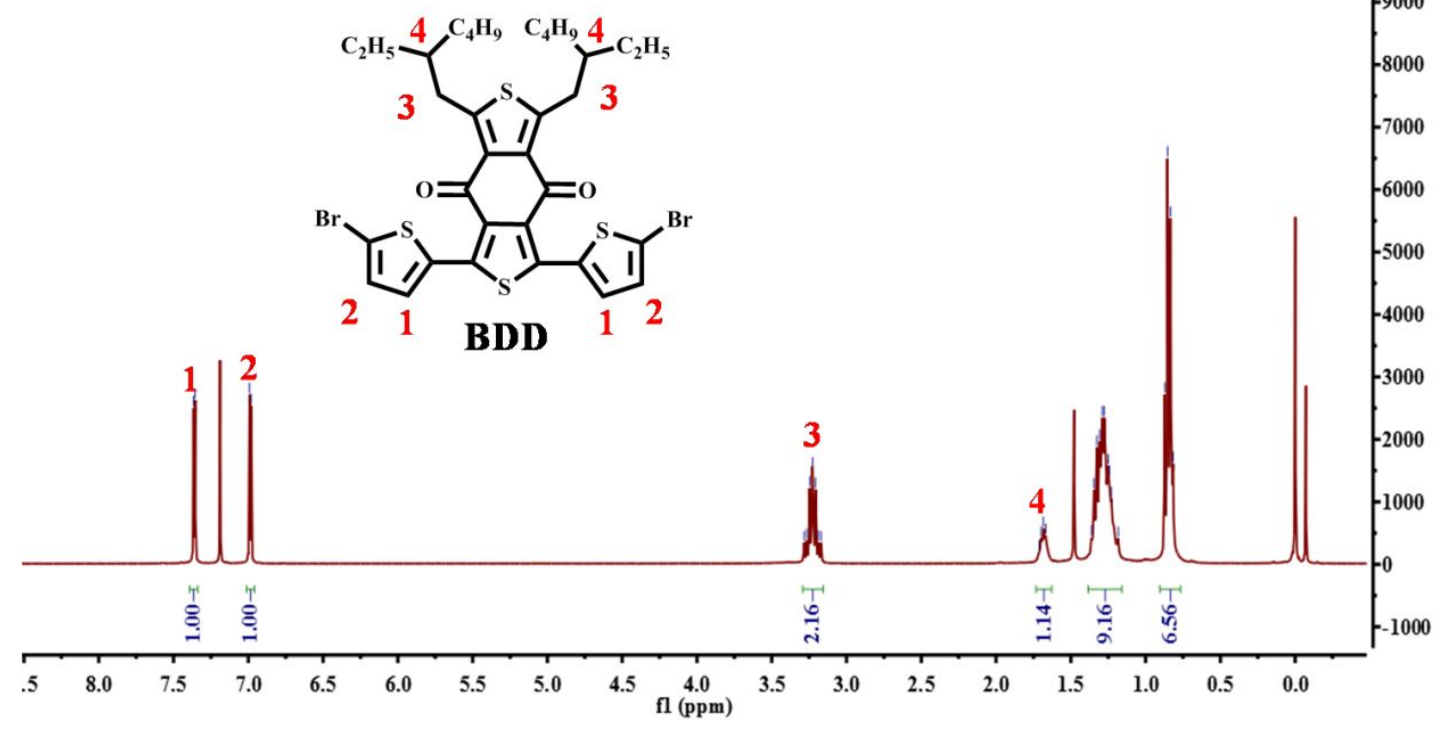

雚

(b)

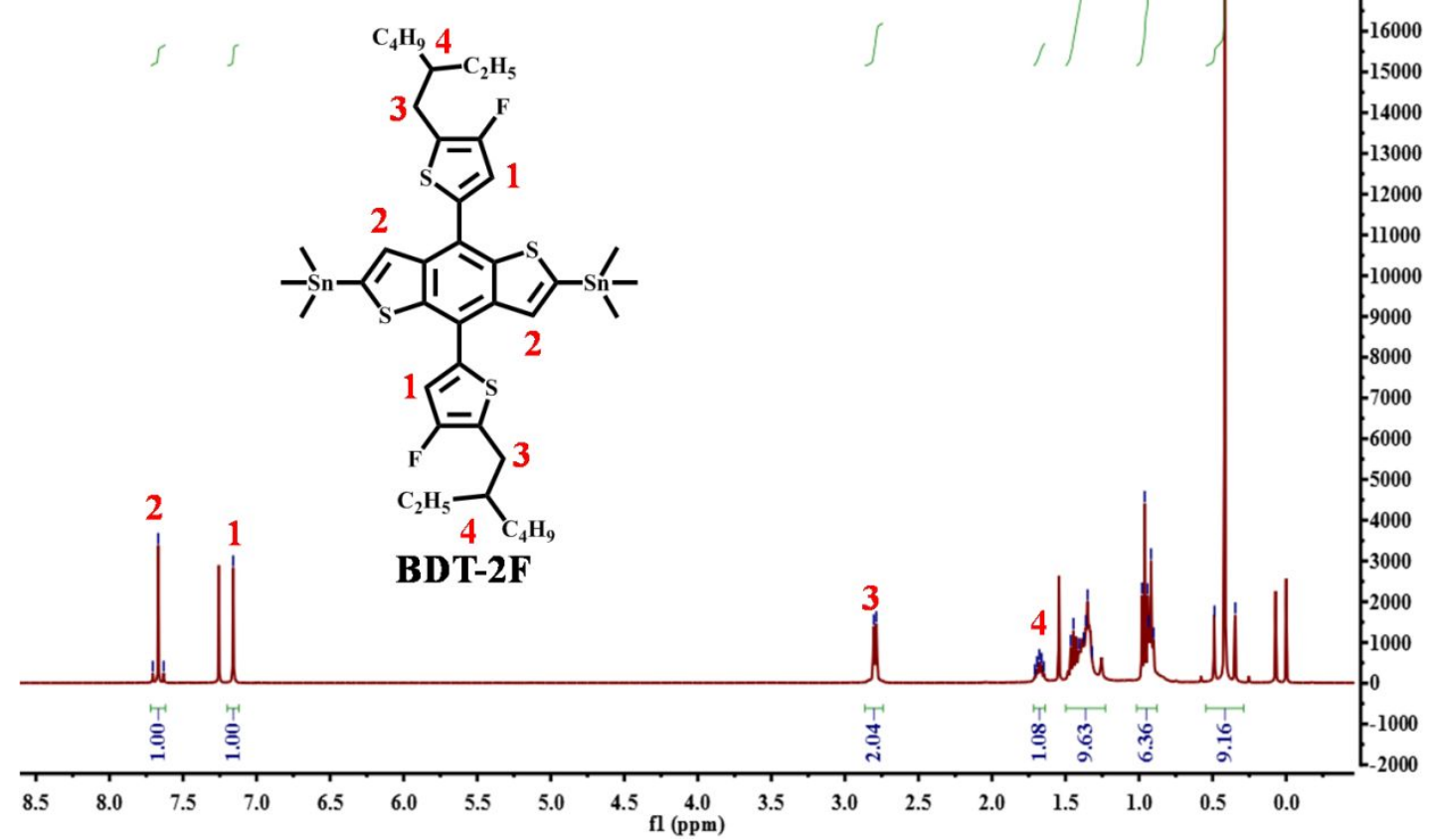

نำ

20000

19000

18000

17000

5000

12000

10000

9000

7000

6000

3000 


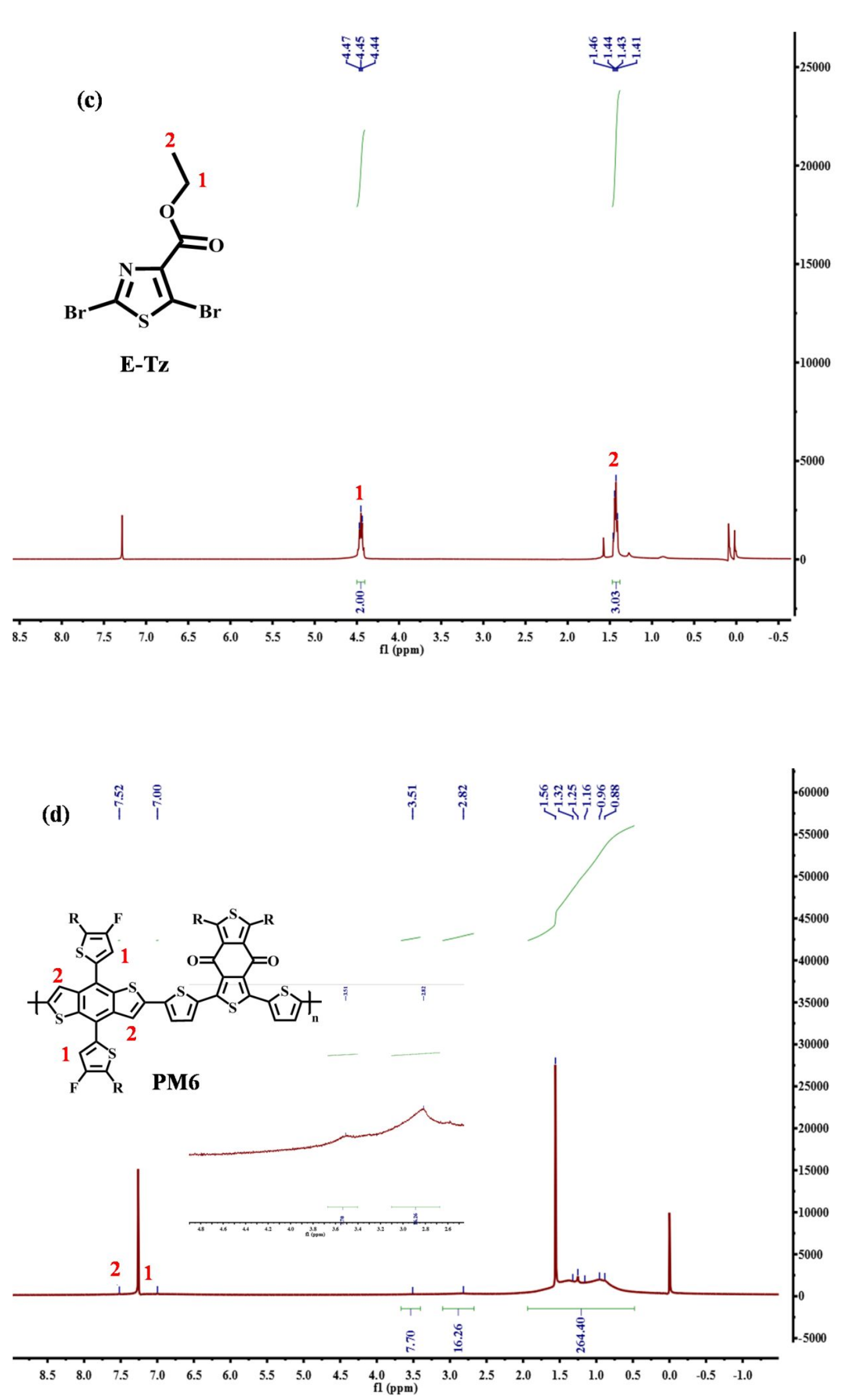




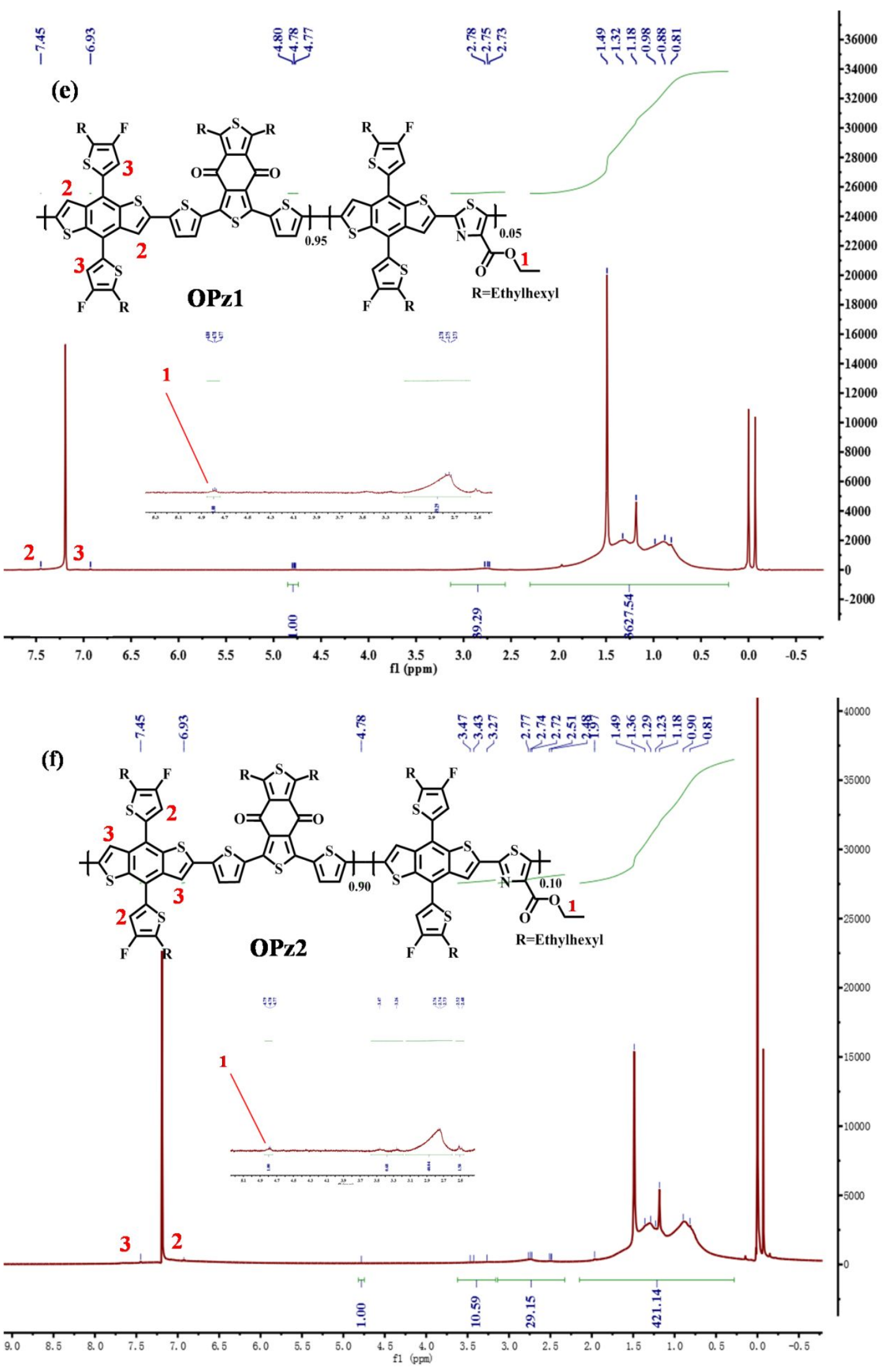



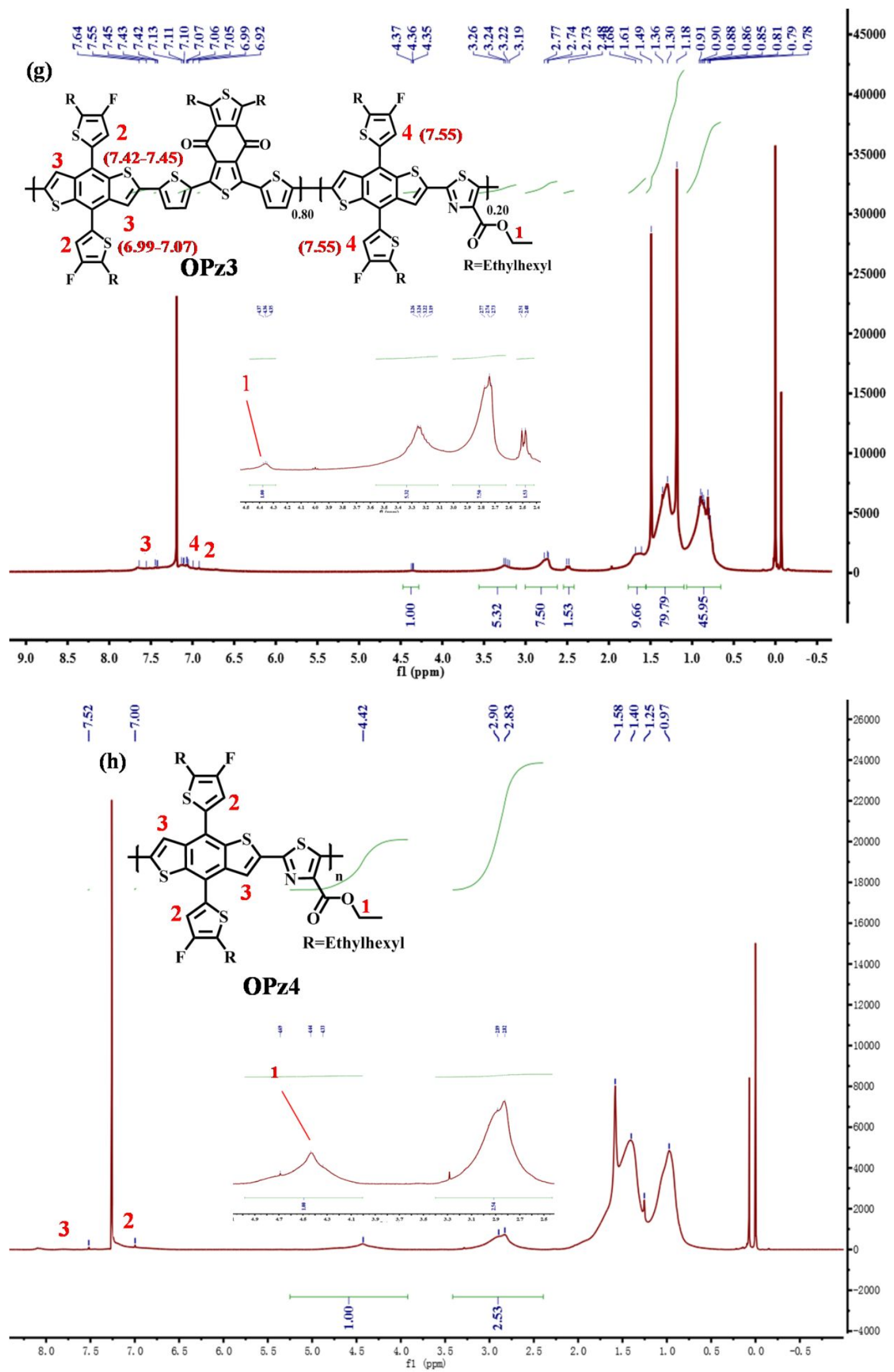

Figure S1. ${ }^{1} \mathrm{H}$ MNR data of the initial monomers and final copolymers in this work. 


\section{Device Fabrication}

Traditional devices based on polymers and Y6 were fabricated according to following procedure. The ITO glass substrates were cleaned followed by ultrasonic treatment in detergent deionized water, acetone, and isopropyl alcohol for $30 \mathrm{~min}$. each. After treating with plasma for $3 \mathrm{~min}$. PEDOT:PSS layer spin-cast on top of the ITO substrates at $4000 \mathrm{rpm}$ for $20 \mathrm{~s}$ and generated at $160{ }^{\circ} \mathrm{C}$ in ambient atmosphere for 30 min. Active layer were spun at $2800 \mathrm{rpm}$ for $30 \mathrm{~s}$ from the solution of polymers:Y6 at weight ratio of 1:1.3 with total concentration of $17 \mathrm{mg} \mathrm{ml}^{-1}$ in $\mathrm{CF}$ as solvent, and then thermal annealing with $100{ }^{\circ} \mathrm{C}$ for $10 \mathrm{~min}$. The Phen-NaDPO (DPO) as the electron-transporting layer, was spin coated on the active layer by $2,000 \mathrm{rpm}$ for $20 \mathrm{~s}$ from an isopropyl alcohol solution $(0.5 \mathrm{mg} / \mathrm{ml})$. Finally, drying Ag layer with a thickness of about $90 \mathrm{~nm}$ were deposited onto the active layer under vacuum of about $2 \times 10^{-6}$ Torr. The surface area of the OPV cells is $11 \mathrm{~mm}^{2}$, and the active layer was processed at room temperature condition. 
(a)
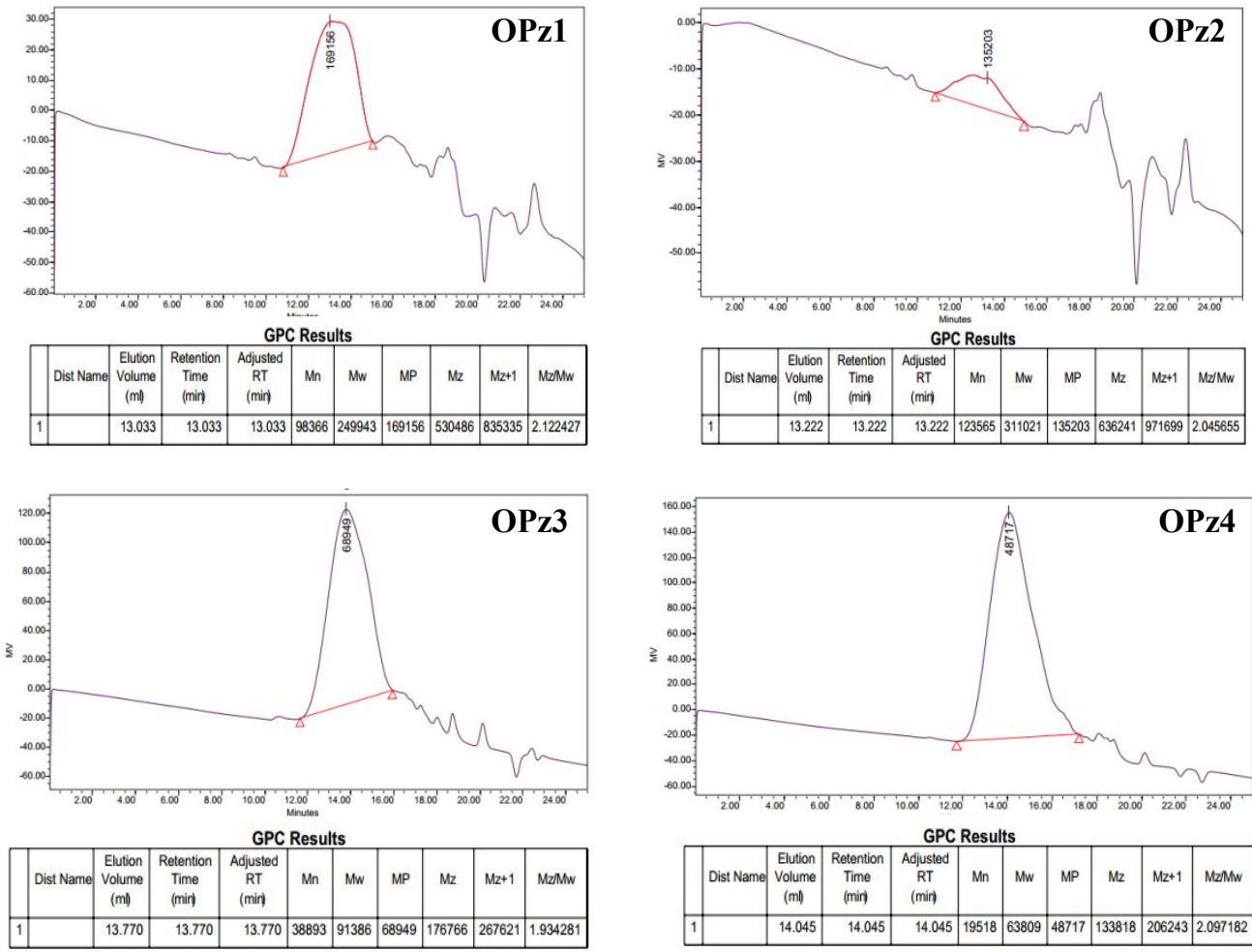

(b)
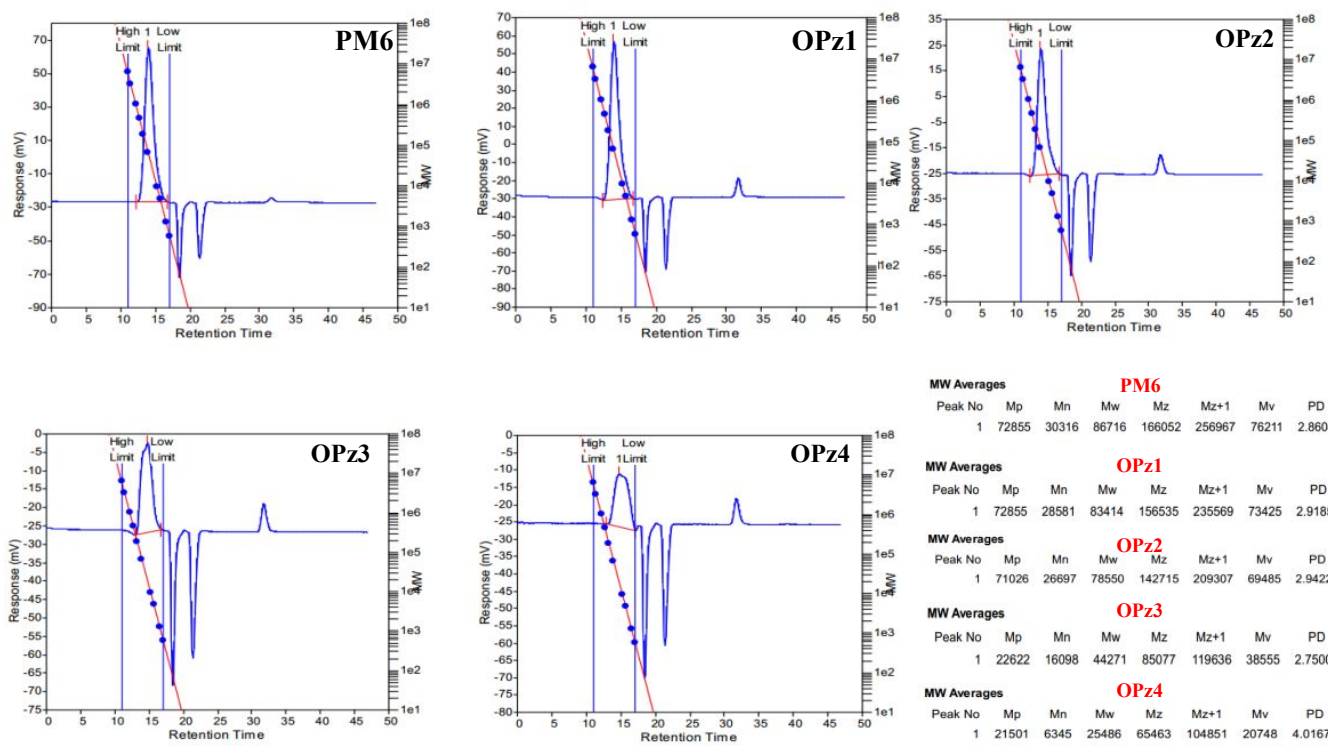

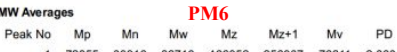

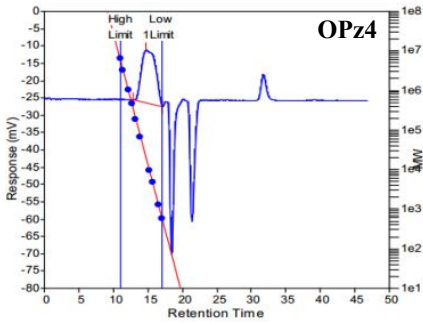

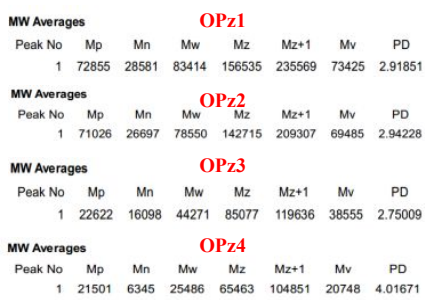

Figure S2. The gel permeation chromatography (GPC) measurements of PM6, OPz1, OPz2, OPz3 and OPz4. (a) In tetrahydrofuran (THF) at room temperature. (b) In trichlorobenzene (TCB) at high temperatures $\left(150^{\circ} \mathrm{C}\right)$. 
(a)

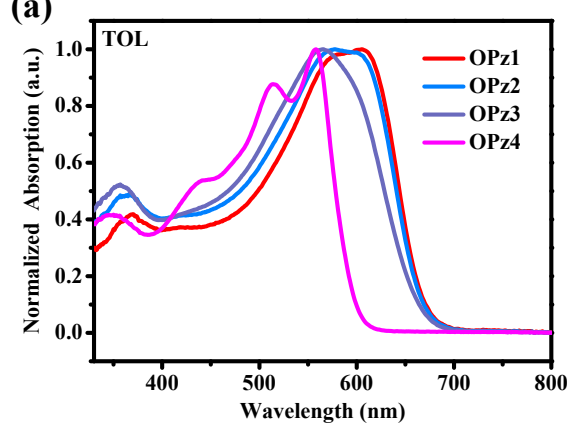

(b)

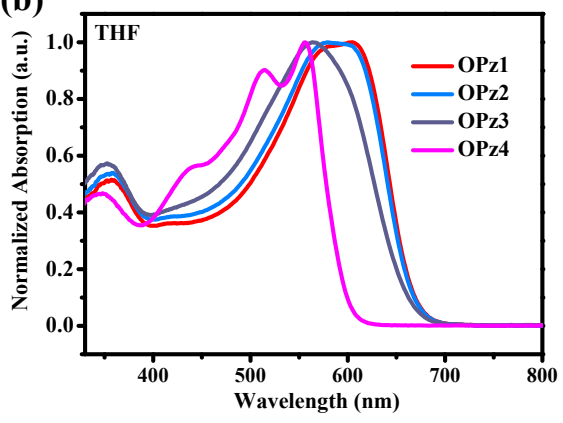

Figure S3. Solution absorption spectra of the polymers in tetrahydrofuran and toluene.
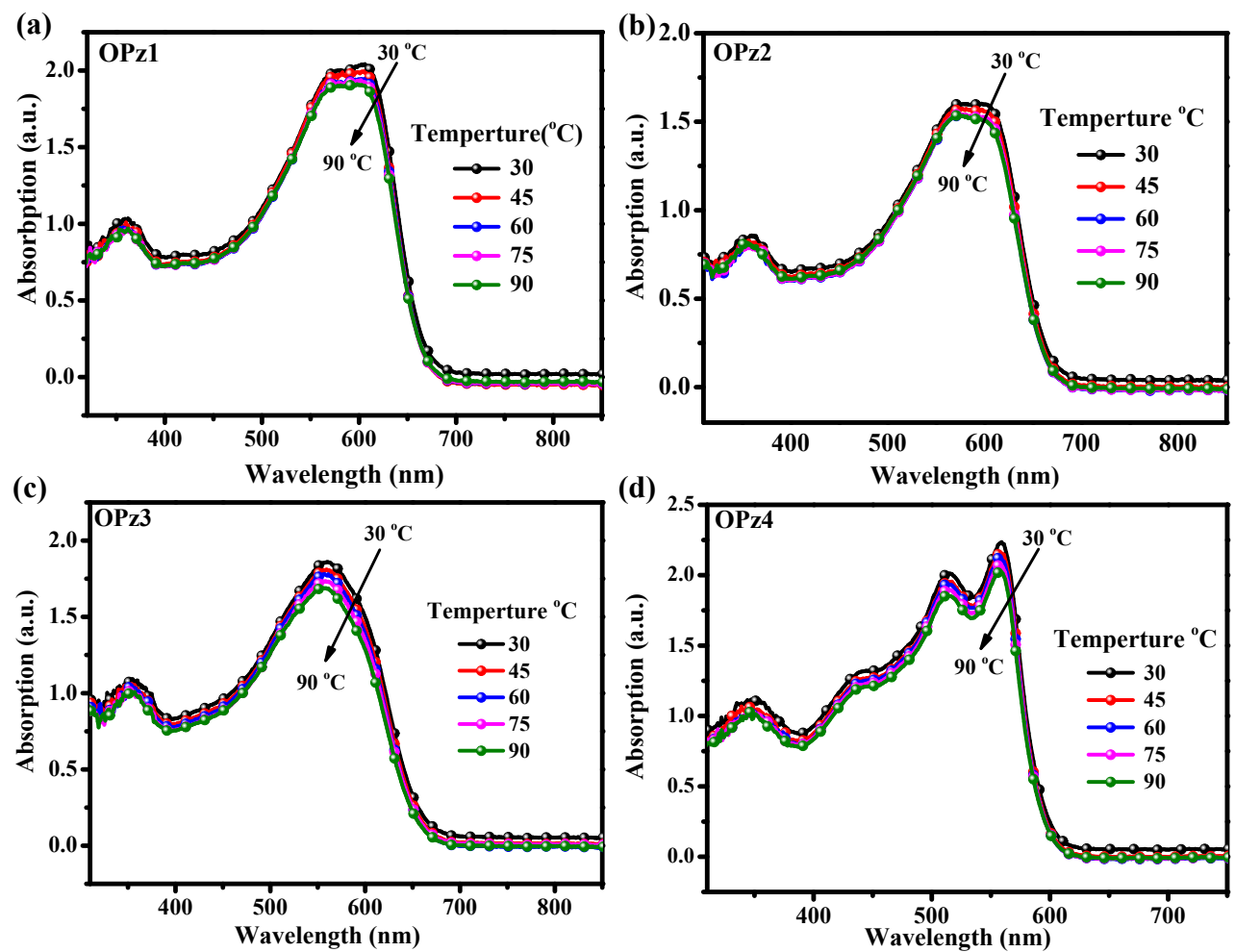

Figure S4. The UV-vis absorption of OPz1, OPz2, OPz3 and OPz4 in chlorobenzene at different temperatures. 


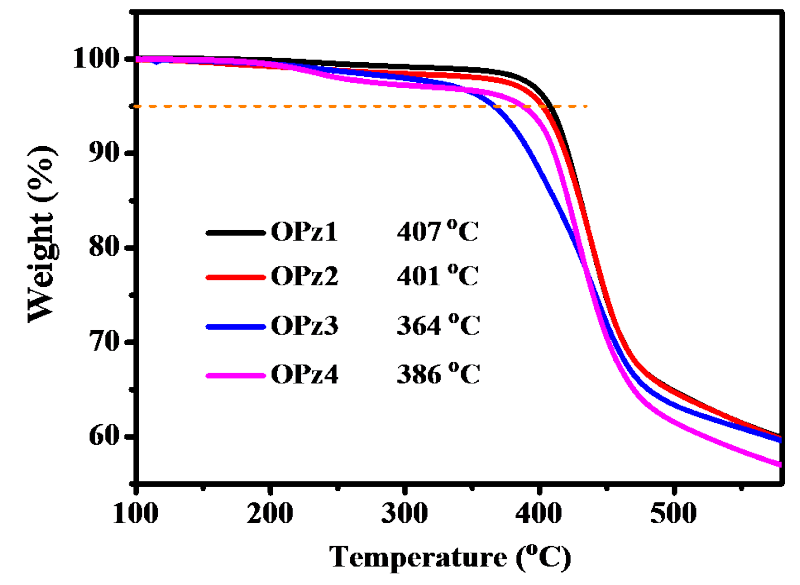

Figure S5. The thermal stability of OPz1, OPz2, OPz3 and OPz4.

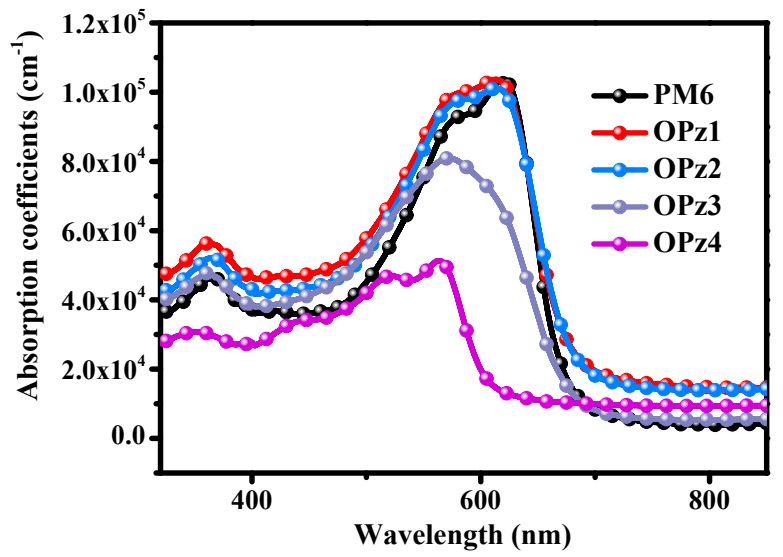

Figure S6. The maximum absorption coefficients for PM6, OPz1, OPz2, OPz3 and OPz4. 


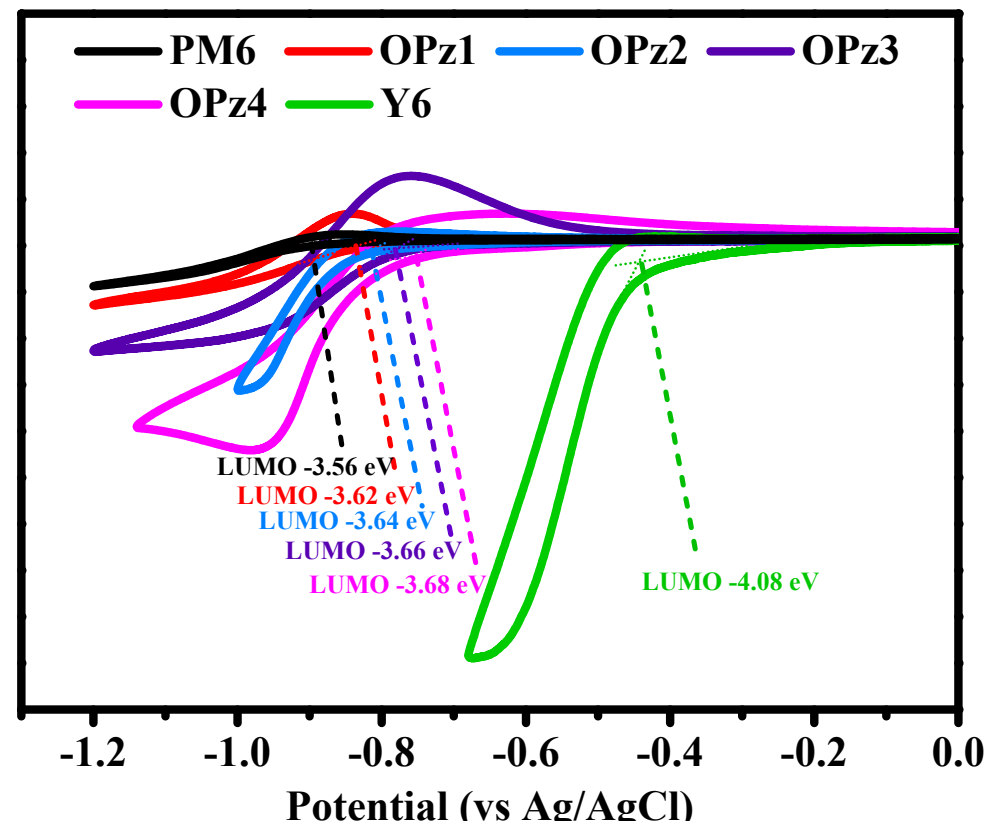

Figure S7. The LUMO energy levels of PM6, OPz1, OPz2, OPz3, OPz4 and Y6 obtained by CV measurements.

Table S1. The detailed device optiming processes of OPz1:Y6-based device.

\begin{tabular}{|c|c|c|c|c|c|c|c|c|}
\hline $\begin{array}{r}\text { Active } \\
\text { layer }\end{array}$ & $\begin{array}{l}\text { Conc. } \\
(\mathrm{mg} / \mathrm{ml})\end{array}$ & $\mathbf{D} / \mathbf{A}$ & $\begin{array}{l}\text { Annealing } \\
\text { Temp. }\left({ }^{\circ} \mathrm{C}\right)\end{array}$ & $\begin{array}{c}\text { Additive } \\
\text { (vol \%) }\end{array}$ & $V_{o c}(V)$ & $\begin{array}{c}J_{\mathrm{sc}} \\
\left(\mathrm{mA} \mathrm{cm}^{-2}\right)\end{array}$ & $\begin{array}{c}\text { FF } \\
(\%) \\
\end{array}$ & $\begin{array}{c}\mathbf{P C E}_{\text {best }} \\
(\%)\end{array}$ \\
\hline \multirow{17}{*}{$\begin{array}{l}\text { OPz1: } \\
\text { Y6 }\end{array}$} & \multirow{7}{*}{16} & $2: 1$ & none & none & 0.860 & 23.40 & 65.07 & 13.09 \\
\hline & & $1.5: 1$ & none & none & 0.860 & 23.47 & 65.99 & 13.32 \\
\hline & & $1: 1$ & none & none & 0.880 & 24.38 & 63.01 & 13.52 \\
\hline & & $1: 1.2$ & none & none & 0.865 & 24.50 & 63.52 & 13.38 \\
\hline & & $1: 1.3$ & none & none & 0.871 & 24.05 & 66.57 & 13.93 \\
\hline & & $1: 1.5$ & none & none & 0.870 & 24.30 & 59.99 & 12.69 \\
\hline & & $1: 2$ & none & none & 0.870 & 21.81 & 63.23 & 12.04 \\
\hline & 17 & $1: 1.3$ & none & none & 0.871 & 24.83 & 66.07 & 14.41 \\
\hline & 18 & $1: 1.3$ & none & none & 0.871 & 24.07 & 66.45 & 14.07 \\
\hline & 17 & $1: 1.3$ & 130 & \multirow{6}{*}{$\begin{array}{c}\mathrm{CN} \\
(0.5 \%)\end{array}$} & 0.870 & 24.21 & 67.0 & 14.11 \\
\hline & 17 & $1: 1.3$ & 120 & & 0.870 & 25.15 & 65.33 & 14.54 \\
\hline & 17 & $1: 1.3$ & 110 & & 0.870 & 24.96 & 66.49 & 14.43 \\
\hline & 17 & $1: 1.3$ & 100 & & 0.870 & 25.19 & 68.72 & 15.23 \\
\hline & 17 & $1: 1.3$ & 90 & & 0.871 & 24.12 & 68.03 & 14.42 \\
\hline & 17 & $1: 1.3$ & 80 & & 0.871 & 24.10 & 66.31 & 14.13 \\
\hline & 17 & $1: 1.3$ & \multirow{2}{*}{100} & $\begin{array}{c}\mathrm{CN} \\
(0.8 \%)\end{array}$ & 0.870 & 25.37 & 73.70 & 16.28 \\
\hline & 17 & $1: 1.3$ & & $\begin{array}{c}\mathrm{CN} \\
(1.0 \%)\end{array}$ & 0.863 & 25.41 & 70.52 & 15.41 \\
\hline
\end{tabular}


(a)

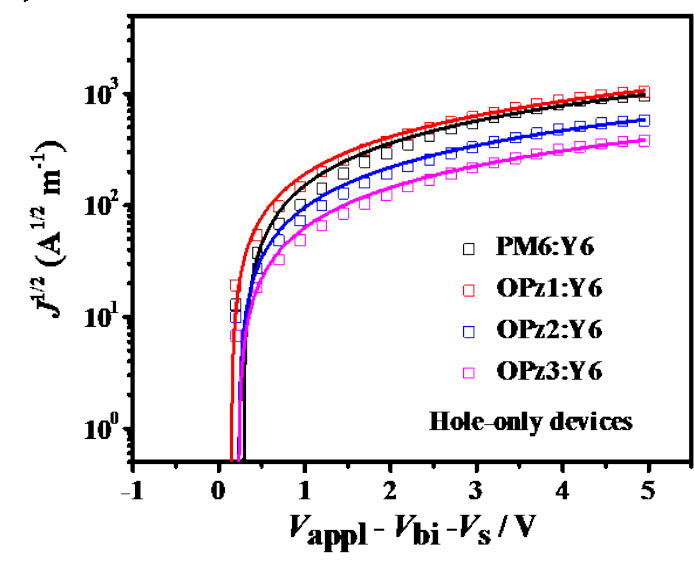

(b)

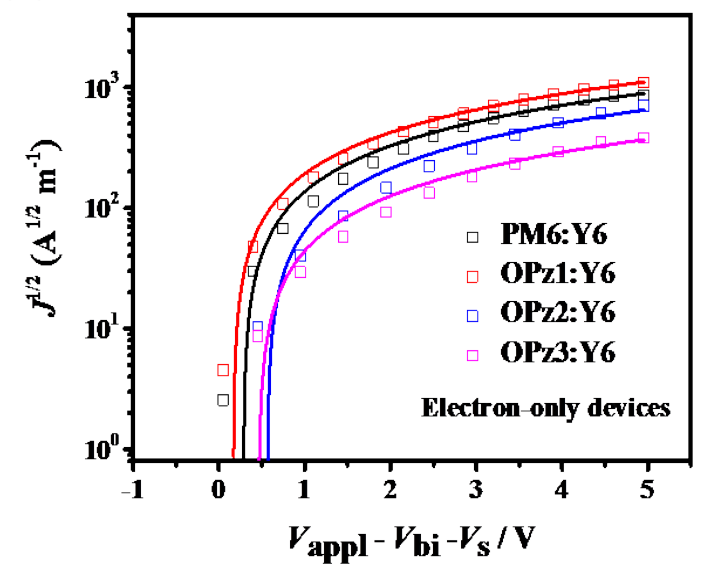

Figure S8. The charge mobilities of OPz1-based, OPz2-based, OPz3-based and OPz4-based devices(fitted curves).

Table S2. The charge mobilities of the devices.

\begin{tabular}{|c|c|c|c|c|c|}
\hline \multirow{2}{*}{ Devices } & \multirow{2}{*}{$\begin{array}{c}\text { Hole } \\
\text { mobilities }\left(\mu_{\mathrm{h}}\right) \\
\left(\mathrm{cm}^{2} \mathbf{V}^{-1} \mathbf{s}^{-1}\right)\end{array}$} & \multirow{2}{*}{$\begin{array}{l}\text { Electron mobiliyies } \\
\qquad\left(\mu_{\mathrm{e}}\right)\left(\mathrm{cm}^{2} \mathbf{V}^{-1} \mathbf{s}^{-1}\right)\end{array}$} & \multirow{2}{*}{$\mu_{\mathrm{h} /} \mu_{\mathrm{e}}$} & \multicolumn{2}{|c|}{$\begin{array}{c}\text { Thickness } \\
\text { (nm) }\end{array}$} \\
\hline & & & & $\mu_{\mathrm{h}}$ & $\mu_{\mathrm{e}}$ \\
\hline PM6:Y6 & $6.32 \times 10^{-4}$ & $4.98 \times 10^{-4}$ & 1.26 & 115 & 120 \\
\hline OPz1:Y6 & $6.76 \times 10^{-4}$ & $5.48 \times 10^{-4}$ & 1.23 & 110 & 117 \\
\hline OPz2:Y6 & $5.25 \times 10^{-4}$ & $2.74 \times 10^{-4}$ & 1.91 & 113 & 122 \\
\hline OPz3:Y6 & $2.28 \times 10^{-4}$ & $9.38 \times 10^{-5}$ & 2.43 & 108 & 115 \\
\hline
\end{tabular}




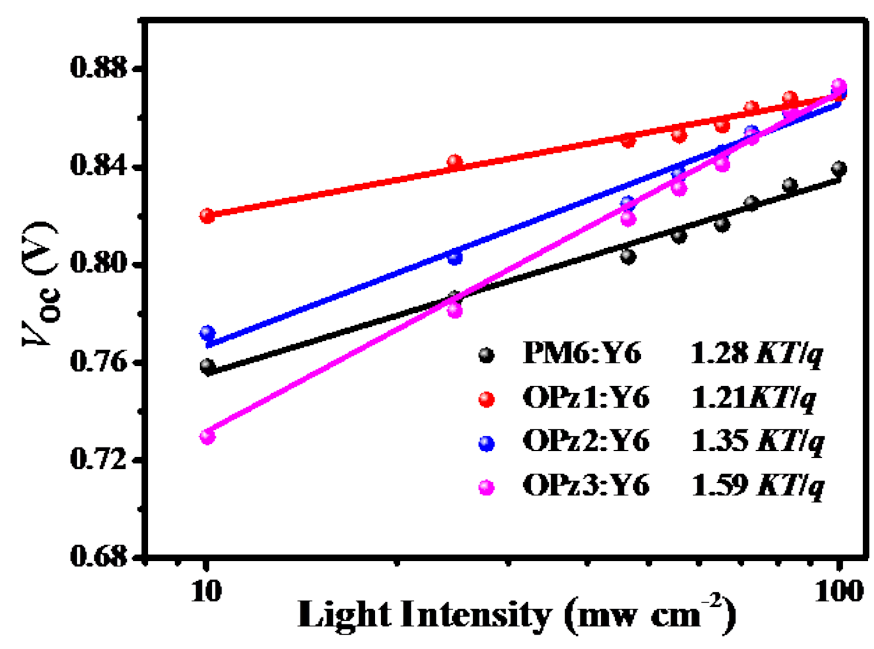

Figure S9. The $V_{\text {oc }}$ versus light intensity for PM6:Y6, OPz1:Y6, OPz2:Y6 and OPz3:Y6 devices.

(a)
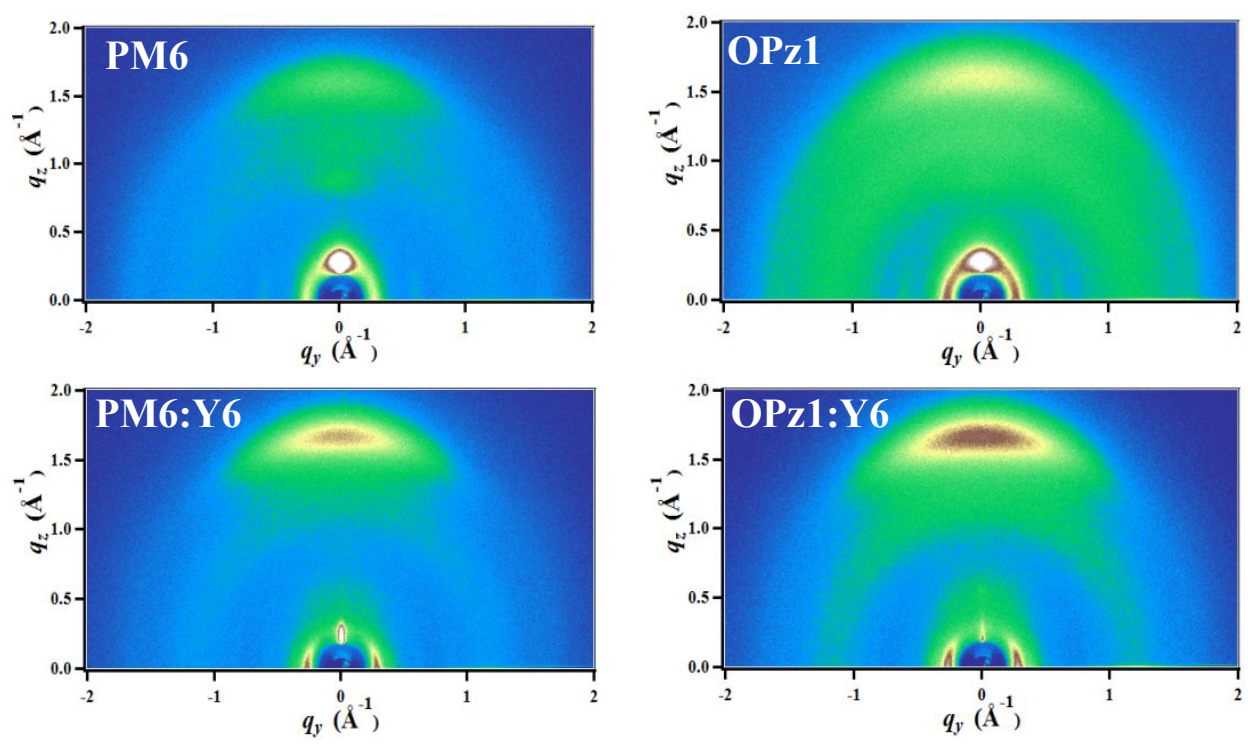

(b)
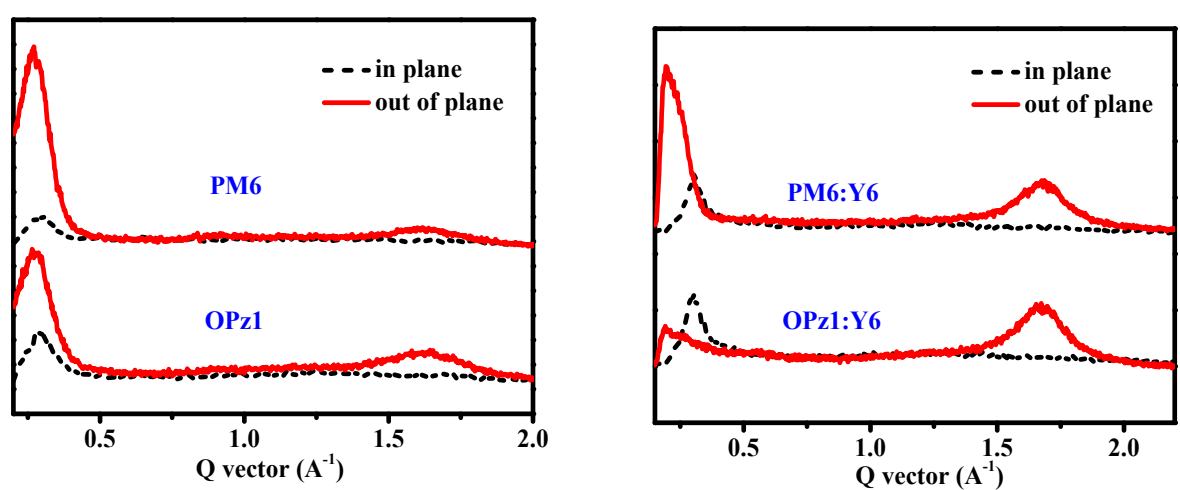

Figure S10. (a) GIWAXS images of PM6, and OPz1 neat and blend film. (b) GIWAXS intensity profiles along the in-plane (dotted line) and out-of-plane (solid line) directions. 


\section{REFERENCES}

(1) Song, J.; Li, C.; Zhu, L.; Guo, J.; Xu, J.; Zhang, X.; Weng, K.; Zhang, K.; Min, J.; Hao, X.; Zhang, Y.; Liu, F.; Sun, Y. Ternary Organic Solar Cells with Efficiency $>16.5 \%$ Based on Two Compatible Nonfullerene Acceptors. Adv. Mater. 2019, 31 (52), 1905645.

(2) Zhang, J.; Liu, W.; Zhou, G.; Yi, Y.; Xu, S.; Liu, F.; Zhu, H.; Zhu, X. Accurate Determination of the Minimum HOMO Offset for Efficient Charge Generation using Organic Semiconducting Alloys. Adv. Energy Mater. 2019, 10 (5), 1903298.

(3) Xue, L.; Yang, Y.; Xu, J.; Zhang, C.; Bin, H.; Zhang, Z. G.; Qiu, B.; Li, X.; Sun, C.; Gao, L.; Yao, J.; Chen, X.; Yang, Y.; Xiao, M.; Li, Y. Side Chain Engineering on Medium Bandgap Copolymers to Suppress Triplet Formation for High-Efficiency Polymer Solar Cells. Adv. Mater. 2017, 29 (40), 1703344. 